\title{
Environmental Impact of Lefa Gold Mining on Its Local Population, Republic of Guinea
}

\author{
Benjamin Kolie ${ }^{1,2}$, Jun Yao $^{2 *}$, Geoffrey Sunahara², Lucie Duonamou ${ }^{3}$ \\ ${ }^{1}$ Department of Mine, Institute of Mine and Geology of Boke, Conakry, Guinea \\ ${ }^{2}$ School of Water Resources and Environment, Department of Environment Engineering, China University of Geosciences \\ (Beijing), Beijing, China \\ ${ }^{3}$ School of Nature Conservation, Beijing Forestry University, Beijing, China \\ Email: *yaojun@cugb.edu.cn
}

How to cite this paper: Kolie, B., Yao, J., Sunahara, G. and Duonamou, L. (2019) Environmental Impact of Lefa Gold Mining on Its Local Population, Republic of Guinea. Natural Resources, 10, 305-323. https://doi.org/10.4236/nr.2019.108020

Received: July 24, 2019

Accepted: August 19, 2019

Published: August 22, 2019

Copyright (c) 2019 by author(s) and Scientific Research Publishing Inc. This work is licensed under the Creative Commons Attribution International License (CC BY 4.0).

http://creativecommons.org/licenses/by/4.0/

\section{cc) (i) Open Access}

\begin{abstract}
Republic of Guinea's environmental situation is characterized by the continued degradation of natural resources. Lefa gold mine is one of the Guinean Republic's gold companies which support the socioeconomic improvement. It operates in the northeastern part of the country and extracts the ore gold by open pit method by using cyanide. The exploitation of the Lefa Gold Mine impacts the natural resources and the surrounding population. This paper considers the impact of Lefa Gold Mine activities on the environment and its local population including ecological disturbance, destruction of fauna and flora, land and landscape degradation. The study was carried out in April to July 2013 in two villages, Fayalala Carrefour, and Lèro Karta. Questionnaires were illustrated for data collection, and the proposed sampling size number (1204 respondents) consisted of the two villages and the surrounding villages was founded on the proximity to the mine sites and their degree of suffering after a direct impact of mining activities. 961 (79.82\% of respondents) adhered to the research to provide information about the situation. The principal objective of this paper was to provide new information on the problems existing in the achievement of mining policies that will help to mitigate the environmental impacts of gold mining activities on the local population. From the respondents, the results showed that the Lefa gold mine's activities contaminated the farmland (31.21\%), allowed the extinction of many animals and plant species (28.19\%), which caused the change of the landscape of the study area. However, the most important situation was the life of the surrounding population. Therefore, the study has proposed a serial of recommendation to help Lefa gold mine reduce the impact of their activities on the environment and local population.
\end{abstract}




\section{Keywords}

Gold Mining, Environmental Impact, Socioeconomic Impact, Cyanide

\section{Introduction}

Natural resource exploitation is a fundamental condition for human living, historically humans have manipulated natural resources to obtain the materials they need, these natural resources are divided into two, the exhaustible such as minerals and the inexhaustible, such as forest and grassland [1]. Many countries carry out an economic development by resorting to the extraction of various natural resources [2]. As a result, the Republic of Guinea is an African country, one of the sub-Saharan countries rich in natural resources and has a population of about 12 million. Apart from the other socioeconomic activities such as agriculture, and fishing, the mining sector plays an important role in the socioeconomic development of the country [3]. The Guinean basement is full of important gold resources that can make Guinea a powerful Gold-producing country. Apart from Ghana, Mali, and Burkina Faso, Guinea is one of the top gold producers in Africa [4]. This potential has been proved by the recent gold discoveries of commercially viable gold deposits as a result of the increased gold exploration activities in the country. The increase of these activities is accompanied by soil degradation and vegetation cover, leading to global phenomena erosion, disturbance of water regimes, loss of soil fertility, and disappearance of important fractions of biodiversity [5].

Mining activities can involve the removal of mineral by producing several raw materials which have lots of environmental and humans health impact [6]. $\mathrm{Hu}$ man collaboration with the environment have been studied and the risks can significantly impact human health, either directly by exposing the population to noxious agents, or indirectly, by troubling life durable ecosystems [7]. In the case of the mining industry, rocks are extracted because of their richness in recoverable ores, however, even with interesting concentrations, the ores seldom have a purity sufficient to be completely transformed into finished products. This causes industries to include ore processing with the use of several processes for extracting gold ore. Faced with this situation, the industry unanimously recognized that imperative measures to conserve natural environments are necessary [8]. Most of the gold produced per year around the world is extracted with mercury or cyanide leaching techniques. The United States, China, Australia, Russia, and the African countries are the largest producers that contribute to the worldwide gold supply [9]. In recent years, cyanide is mostly used for gold processing and is an economically viable process for extracting gold ore [9]. It is a weak and strong dissociable acid that is governed by chemical and biological processes. Cyanide is formed by strong bonds between passage metals and carbon atoms of cyanide and the most toxic are free cyanide [10]. The use of cyanide to transform these 
natural resources remains the best technique then the key problem must be found between favor of natural resources and sometimes at the costs of technology that must necessarily adapt. This attitude of safeguard the environment and ecology are explained by the fact that these resources are gifts of nature that need to be well managed to maintain a certain balance with an improvement of the living conditions of current and future populations [11].

The Lefa gold mine production in 2017 in Guinea was estimated at 968,300 ounces of gold and was operated by Nordgold worldwide. The exploitation method at the Lefa gold mine (LGM) is by the open pits, and the gold panning has been practiced all over the mine site [12]. Lefa mine has actually a priority sector to develop and improve socioeconomic conditions in Lèro and surrounding villages [13] but it discharges chemical toxic compound that can reach the surface water bodies during the rainy season by the chemical process such as acid mining drainage, thereby exposing workers and residents to a health risk including respiratory problems and other diseases [11] [14]. This paper looks at the impact on the environment, health and socioeconomic activities directly connected to the mine activities. In addition to analysis of relationships between resource extraction and socioeconomic factors such as poverty or unemployment, the study has investigated that the LGM in particular often pursue a wide range of non-commercial goals such as job creation or improving local social services or infrastructure by directly funding schools, hospitals, roads, electricity, and sanitation [15].

A news website (https://www.guineenews.org/) reported on November 18-2018 that the processing discharge of Lefa mine tailing lake is located a few hundred meters from the village Fayalala Carrefour, where about 1700 people live shown in (Figure 1). During the first half of July 2015, residents faced the first grave incident when the settling pond discharged onto the lake that was used by the community for domestic purposes. Since then, access to drinking water has been difficult for residents. Environmental incidents related to gold processing are often assigned to cyanide in LGM, whether it is involved or not. The study has shown that cyanide is not generally associated with long term environmental impact and can be safely treated and discharged into the environment [16].

In Guinea, there is a significant existing scientific literature on mining in general concept, but more are based on bauxite mine which is the biggest reserve of the country. In the gold mine sector, mining conflicts are the most studied [17] [18] [19] [20]. This study investigated the impact of Lefa gold mine operation on the environment and local population and includes ecological disruption, eradication of fauna and natural flora, land, water, and landscape degradation. The environmental impact of gold mining in developing countries has been well studied [21] [22] [23] [24] but rather the unknowing of the effects and benefits. In most instances, resource-strapped governments are the only bodies capable of efficiently directing regional activities but are burdened with the challenge of regulating for decades an "informal" industry and facilitating environmental improve- 
ments of residential operations. This study will provide new information on the difficulties and problems existing in the achievement of mining policies that will help to mitigate the environmental impacts of gold mining activities on its local population. It will inspire and encourage decision-makers to take into account the socioeconomic and environmental problems of the mining area.

The main objective of this study was to assess the impact of LGM on its local population by 1) evaluating the LGM activities impacts on the environment; 2) Identifying the impacts on the socioeconomic and the natural resources; 3 ) Proposing mitigation measures.

\section{Materials and Methods}

\subsection{Description of the Study Area}

The study was carried out in the northeastern part of Guinea about $\left(10^{\circ} 48^{\prime}\right.$ and $12^{\circ} 36^{\prime}$ north latitude and between $8^{\circ} 42^{\prime}$ and $10^{\circ} 12^{\prime}$ west longitude with an average altitude of $974.9 \mathrm{~m}$ ). It is located about $850 \mathrm{~km}$ from the capital Conakry, near the Malian border and about $10 \mathrm{~km}$ south of Siguirini village [25] (Figure 2(A) and Figure 2(B)). The mine site is located not very far to the populated rural area, where sustenance agriculture and open range cattle grazing are the dominant activities [26]. The study was based on research conducted at gold mining areas in the sub district of Siguirini, the village of Lèro Karta and Fayalala carrefour where these two mining areas have the largest gold reserves in the LGM site, which is named Nord Gold or SMD (Société Minière de Dinguiraye). Lèro Karta (18,004 inhabitants) covers an area of $500 \mathrm{~km}^{2}$ and Fayalala Carrefour (1700 people according to the general population census 2008) Lefa is in the plateau area whose altitude varies between $300-400 \mathrm{~m}$ and characterized by a gravelly soil with occasional rocky outcrops. It belongs to the Sudanese climatic zone, characterized generally by two seasons. The rainy season lasts from April to October and a dry season is from November to March. The average annual rainfall is about $1200 \mathrm{~mm}$ (maxima of $1369 \mathrm{~mm}$ minimum $110 \mathrm{~mm}$ ) shown in Figure 3.

The vegetation type is Savannah and the most characteristic plant formations are herbaceous in the plains and plateaus, along the rivers there are gallery forests. The fauna that once included green monkeys, chimpanzees, warthogs, birds, and reptiles have now become increasingly rare in this area. The Lèro Karta and Fayalala Carrefour belong to the Tinkisso watersheds, which originates about $40 \mathrm{~km}$ south of the mining prospect. This area belongs in part to the high secondary tributary basin of Niger [25].

\subsection{Study Methods}

\subsubsection{Study Design}

The present study research was carried out at the LGM site to assess the environmental and socioeconomic impacts that result from mining activities. A methodology strategy directed by the research questions were particularly suited for 
this study, as more data source provide more relevant data to answer all the research questions.
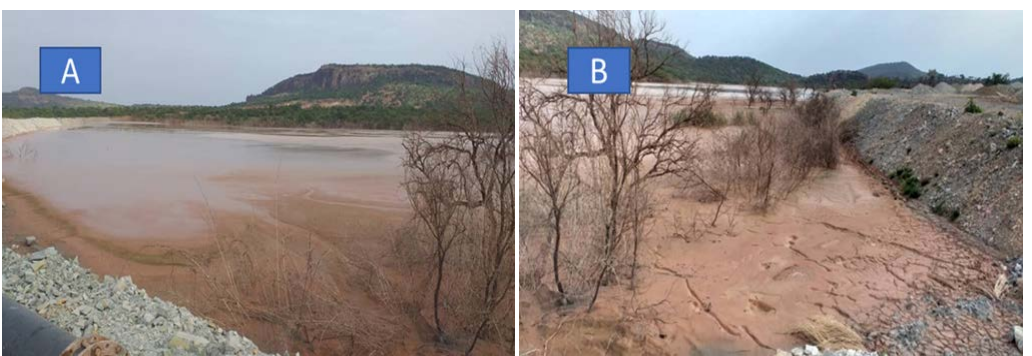

Figure 1. A-B Lefa gold mine tailing dams in Fayalala Carrefour.
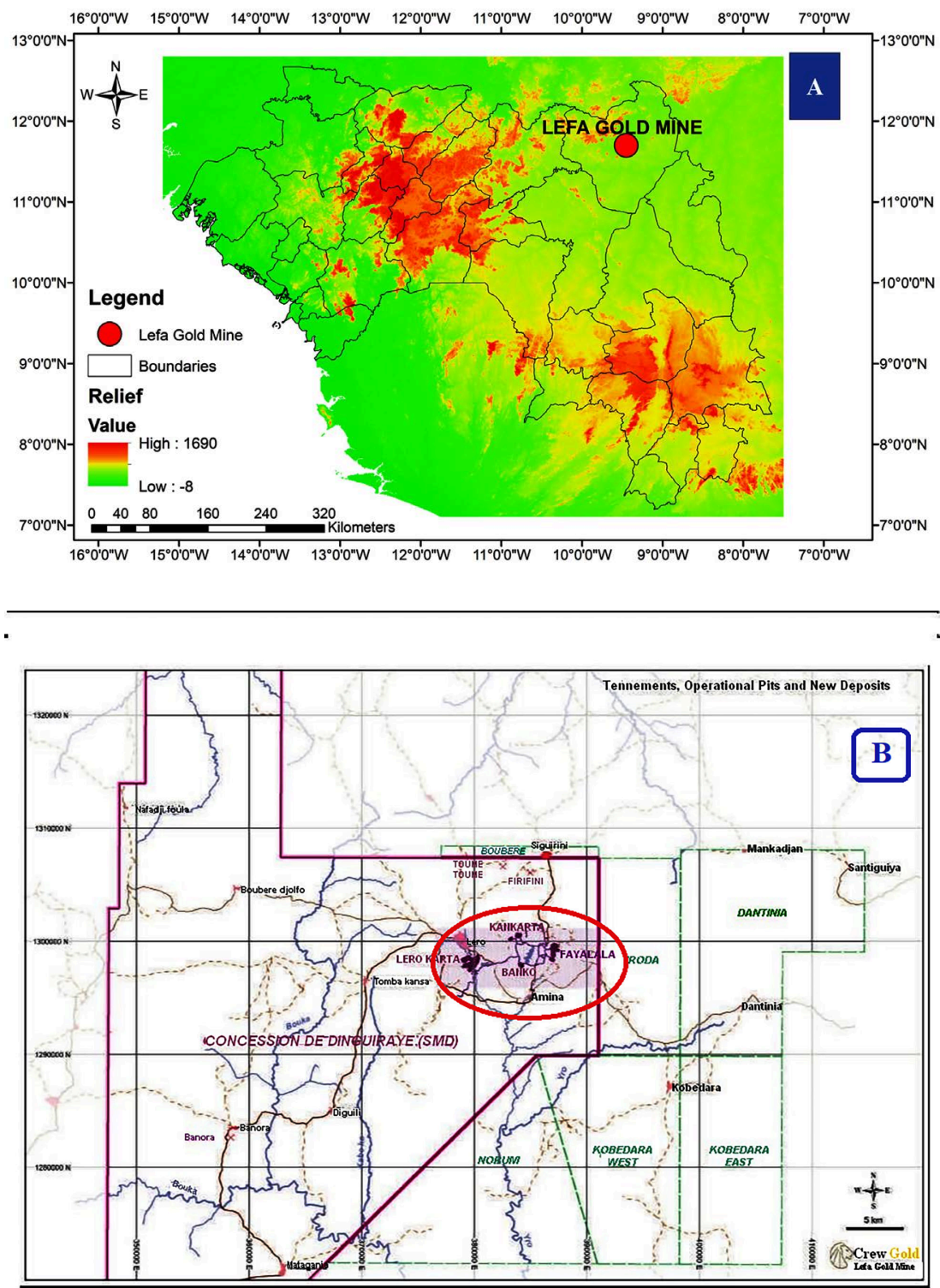

Figure 2. A: Location of the SMD Lefa Gold Mine in Guinea, Africa, B: Location (circle in red showing Lèro Karta and Fayalala Carrefour villages and surrounding villages; Source: Lefa Technical Report Update-November 2009. 


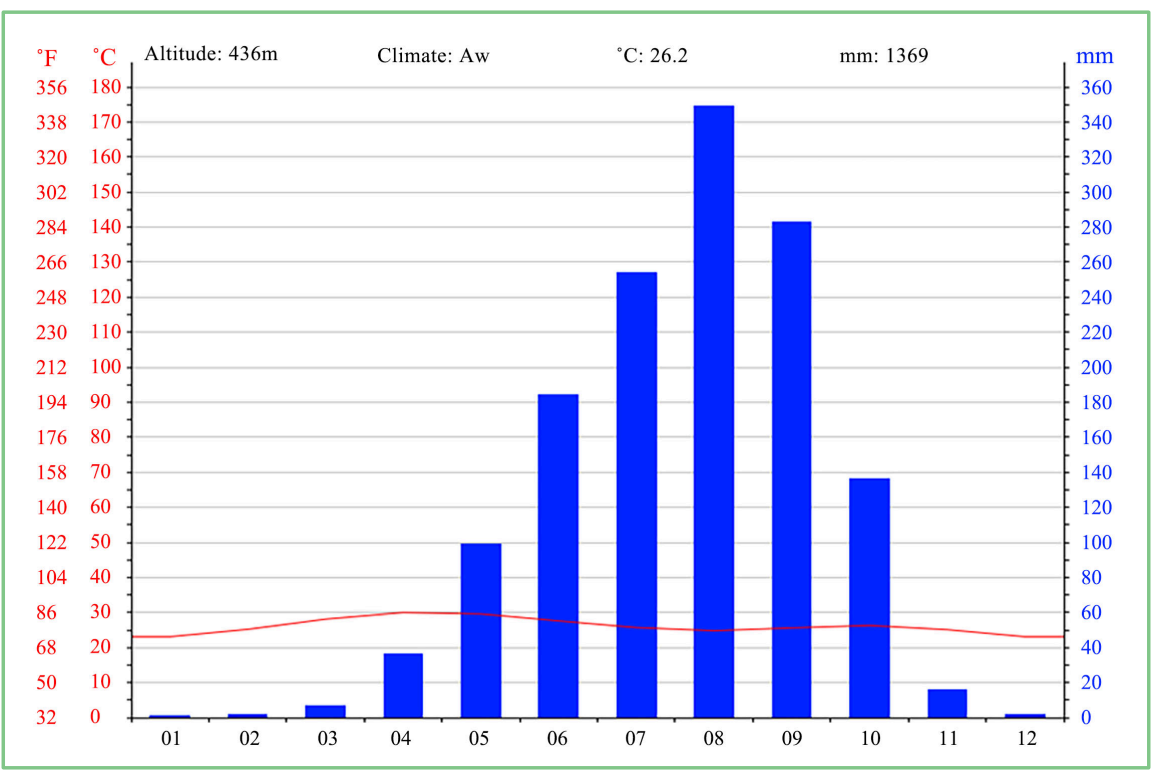

Figure 3. Annual temperature and precipitation in Dinguiraye, from 2001 to 2012. Source: https://fr.climate-data.org/afrique/guinee/region-de-faranah/dinguiraye-766844/.

\subsubsection{Study Population}

The target study population consisted of two main groups: the mining workers and the stakeholders. The mining workers were either active or retired, and have been working for at least 1 year. The stakeholders included residents living in the mining communities, and other local government authorities such as village chiefs, the local government representative, workers' unions, and the Lèro District health community service. The stakeholder's participation was their decision to present a proposal that reflects the various positions of LGM and the government between divergences in a consensus-seeking process. The study adopted stratified random and convenient methods of sampling [27]. The sampling size consisted of Lèro Karta and Fayalala and the surrounding mining villages (Table 1). Quantitatively, it includes 1204 respondents of which 354 Miners and 830 stakeholders, 4 Minetop officials, 8 government Representative, 2 workers unions, and 6 health community service members participated. The proposed sample size number was based on the respondent's proximity to the mine sites and their degree of suffering after a direct impact of mining activities.

\subsection{Source of Data}

The collection of data included the primary and secondary sources of information (Figure 4).

\subsubsection{Primary Data}

Primary data was obtained by using multiple methods, including key informant interviews with staff and stakeholders, Field investigation to correlate the information collected and to be alert for potential sources of bias in other data, The questionnaires were used to the target groups to collect socioeconomic and other data on different way the residents interact with their environment and their life, 
that form the sample size. Questionnaires took about 5 to 10 min answers. Completed questionnaires were collected for data entry and analysis ([27] [28]).

\subsubsection{Secondary Data}

Secondary data was obtained by consulting mining reports, publications in the book, articles from the journal, website news, government report, encyclopedias, Google scholar, local files and project reports related to the topic.

\subsection{Research Instruments}

This study necessitated the use of the following instruments to achieve the work findings.

Table 1. Distribution of the sample size and local residents' perception of gold mining visible environmental impacts.

\begin{tabular}{cccccc}
\hline $\begin{array}{c}\text { Effect of } \\
\text { mining activities }\end{array}$ & $\begin{array}{c}\text { Frequency } \\
\text { of numbers }\end{array}$ & $\begin{array}{c}\text { Percentage } \\
(\%)\end{array}$ & $\begin{array}{c}\text { Scale of } \\
\text { impacts }\end{array}$ & Frequency & $\begin{array}{c}\text { Percentage } \\
(\%)\end{array}$ \\
\hline $\begin{array}{c}\text { Landscape degradation } \\
\text { and pollution }\end{array}$ & 354 & 29.4 & $\begin{array}{c}\text { Very } \\
\text { Significant }\end{array}$ & 300 & 31.21 \\
$\begin{array}{c}\text { Turbidity and } \\
\text { diversion of streams }\end{array}$ & 330 & 27.41 & $\begin{array}{c}\text { Very } \\
\text { Significant }\end{array}$ & 280 & 29.14 \\
$\begin{array}{c}\text { Destruction of fauna } \\
\text { and flora }\end{array}$ & 275 & 22.84 & $\begin{array}{c}\text { Very } \\
\text { Significant }\end{array}$ & 271 & 28.19 \\
$\begin{array}{c}\text { Air pollution } \\
\text { Failure to acknowledge } \\
\text { the impact }\end{array}$ & 145 & 12.04 & insignificant & 40 & 4.16 \\
Total & 1204 & 100 & insignificant & 90 & 9.36 \\
\hline
\end{tabular}

NB: Responses represent respondents' first choice (a lot of them noted more than one visible impact).

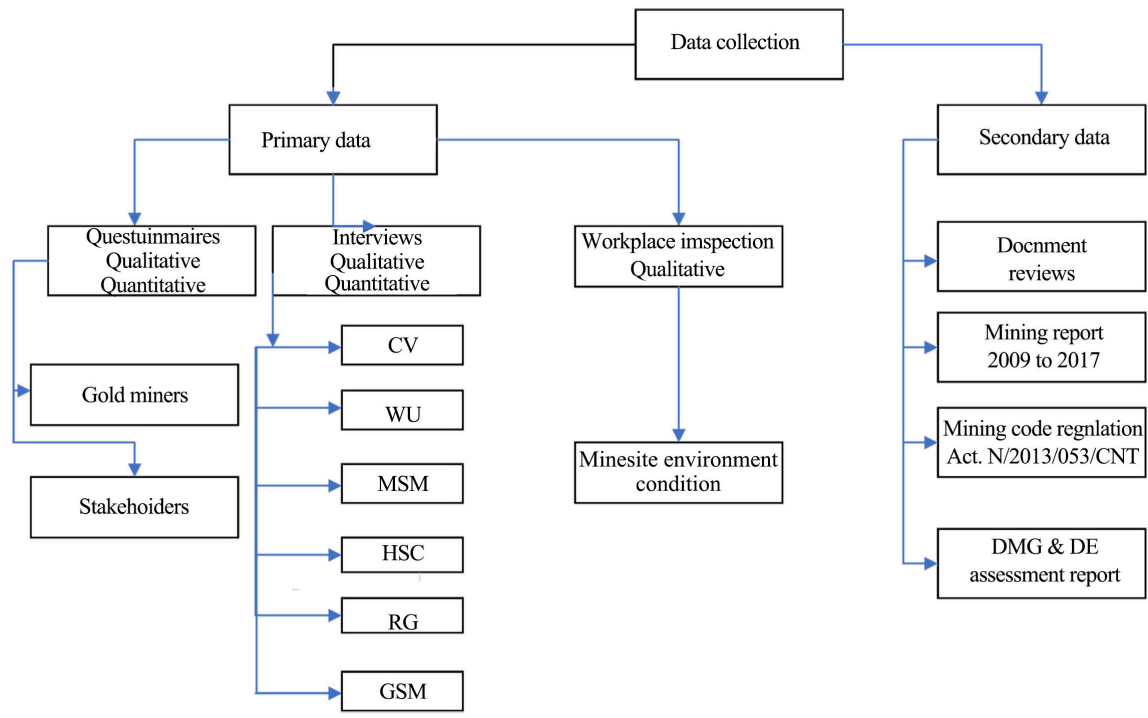

Figure 4. Data source and collection process. CV: Chief of the village; WU: Workers union; MSM: Mining site manager; HSC: Health service community; RG: Government representatives; GSM: General supervisor of mining. 
1) Geographical map to frame the research.

2) Use of the questionnaire was the main survey instrument to collect information's.

3) Documentary analysis of existing literature that refers to the topic.

4) Digital camera for photographic documentation of mine sites.

\subsection{Research Technique}

An investigation was carried out in the field from April to July 2013 to engage stakeholders on the rationale of the research. After field identification or a household in the case of residents, before start asking, the researcher clarifies the purpose of the study. To gain respondent confidence, privacy was assured. Structured and semi-structured interviews were adopted to examine their perceptions of how mining activities impact the environment and the livelihood of the local population. The research investigative work takes into account the prospection which consisted of the enumeration of the Lèro Karta and Fayalala mining wells as well as the inventories which aimed to know the flora and fauna species current condition.

\subsection{Data Analysis}

The collected information was carried out for analysis. The software Microsoft Excel spreadsheet was used to input information in both (primary and secondary) to developed frequency distribution tables' charts, graphs among others.

\section{Results Finding and Discussion}

\subsection{Socio-Economic Impact}

Dotson and Hetman (2002) showed that the open pit-mine and quarries exploitation impact has observable impact on the environment land degradation, destruction of vegetation, and the extinction of the native fauna are the most significant signs. Open-pit mines are also a common source of contamination of surface and ground waters [21]. From the sample size of 1204 respondents in Table 1, only 961 respondents equal to $(79.82 \%)$ indicated that mining affects the surrounding population. $31.21 \%$ (300/961) affirm that landscape degradation has negative aspects of the vegetation in the area and pollution that is showing in Figure 5(C) affects the farmland. 28.19\% (271/961) testify the eradication of fauna and flora.

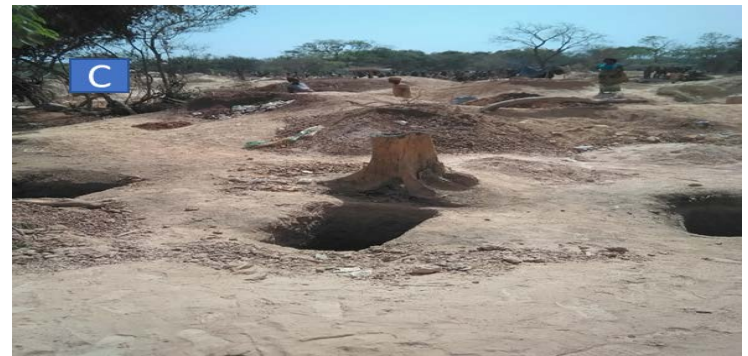

Figure 5. C Scene of soil degradation by artisanal gold mining. 
It is important to know that mining appropriates land appertain to the local communities and the activities impacts their health, alter the social relationship, destruct the forms of community subsistence and life, cause social disintegration by drastic and curt changes in regional cultures [29]. To identify the major impacts on the socioeconomic of LGM on the surrounding villages, respondents were asked to talk generally about what changes they have personally observed over the past five years especially when SMD LGM started operating in the area and to make a comparison to the existing situation. The respondents affirmed the presence of major changes and impacts which has reduced the arable lands, the scarcity of the game because of the noise of mining activities and the destruction of forest, activities also decrease the gold panning areas for environment change and population growth, cattle theft, turbidity of waters as shown in Table 2; Only the village Fayalala Carrefour suffered more negative effects than the other villages that is likely due to the proximity of the lake to residue unlike in the village of Fontou which has notified any effect.

Mining can be an important aspect of the local livelihoods as shown in Table 2 [19]. Here 9.36\% (90/961) affirm that LGM provide a means of survival for the miners and support with good service such as food, tools, and equipment's, but also can change the landscape of the locality by construction of roads for the emergency transport, schools, and hospitals but also assist the community in their education, which was insignificant in the survey. Therefore, social impact evaluation of activities has emerged as a relevant issue regarding both positive and negative impacts. Finally, the defiance is associated with water-related risks, the source of some damages on both the environment and the people. This defiance consists of water balance management, water quality, tailing dam failures, and site rehabilitation [30] [31].

In Table 3, local people were made their living from agriculture, fishing, hunting, breeding, gold panning, and livestock management. Lefa mine activities generally help the national economy to grow, but at the local level communities are faced with many social and environmental problems including destruction or pollution of farmland [21], 31.21\% (300/961) affirm that mining has denuded the land of its nutrients and rendered it infertile for agricultural purposes. Consequently, little farmland was available for farming activities. In most mining communities, "the degradation of land by LGM constitutes a major threat to agriculture in the communities and their economic survival [29]. Much of the still available land has been contaminated with chemicals from mining activities [32] which make higher the living cost and increase mortality rate and diseases. SMD LGM is a priority sector to enhance the development and improvement of the socioeconomic conditions in Lèro and surrounding villages [33], but its activities affect biodiversity at many dimensions (site landscape, regional, ...) through direct or indirect impact [34]. The mining has focused on the use of cyanide which can be toxic to humans and wildlife. Some people conclude that mining, as a whole, should be a regrettable environment incident because we know the risk and we do have to take responsibility to ignore it [16]. 
Table 2. Socio-economic characteristic of respondents in this survey.

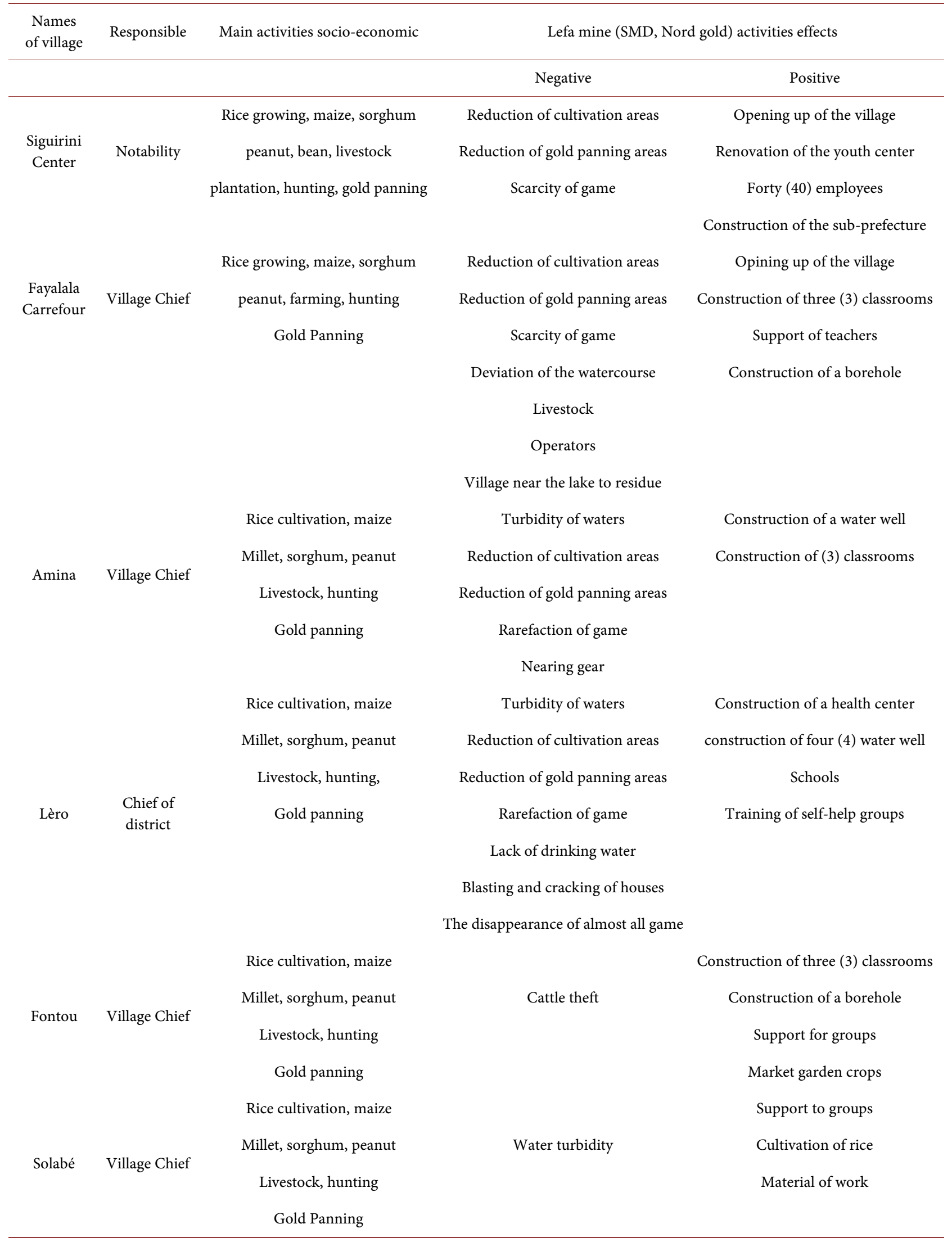


Table 3. Socio-economic impact of mining activities.

\begin{tabular}{|c|c|c|c|}
\hline \multirow{2}{*}{ Activities } & \multicolumn{2}{|l|}{ Impacts } & \multirow[t]{2}{*}{ Recommendations } \\
\hline & Positive & Negative & \\
\hline & & Reduction of cultural spaces & \\
\hline & & Reduced pasture space & Develop agropastoral spaces \\
\hline \multirow[t]{2}{*}{ Breeding } & & The obstacle to the wandering of animals & Monitor animals to avoid uncontrolled rambling \\
\hline & & Tarnishing of rivers & Protect the banks of streams \\
\hline \multirow{3}{*}{ Peach } & & Rarity of fish & Periodic cleaning of watercourses \\
\hline & & Watercourse diversion & Make Fish ponds \\
\hline & & The rarity of the game in the exploitation area & Regulate hunting \\
\hline \multirow{3}{*}{ Hunt } & & & Reduce the noise nuisance \\
\hline & & 1 & Reforest compensation areas with local species \\
\hline & $\begin{array}{l}\text { Pole of attraction of a } \\
\text { part of the population }\end{array}$ & High cost of living & Create micro-credits and economic interest groups \\
\hline \multirow[t]{2}{*}{ Trade } & $\begin{array}{l}\text { Construction of a } \\
\text { market }\end{array}$ & High cost of living & Create micro-credits and economic interest groups \\
\hline & $\begin{array}{l}\text { Construction } \\
\text { of a clinic }\end{array}$ & $\begin{array}{l}\text { Multiplication of diseases by the increase of } \\
\text { population and lack of healthy habitat }\end{array}$ & Increase the number of clinics and health posts \\
\hline \multirow[t]{2}{*}{ Heath } & Disease treatment & $\begin{array}{l}\text { Multiplication of diseases by the increase of } \\
\text { population and lack of healthy habitat }\end{array}$ & $\begin{array}{l}\text { To sensitize the population on the respect of hygienic } \\
\text { conditions }\end{array}$ \\
\hline & School construction & $\begin{array}{l}\text { Abandon of the school for the benefit of } \\
\text { employment within the company or gold panning }\end{array}$ & $\begin{array}{l}\text { Educate parents of students and students about the } \\
\text { importance of studying }\end{array}$ \\
\hline \multirow[t]{2}{*}{ Education } & Teacher support & $\begin{array}{l}\text { Abandon of the school for the benefit of } \\
\text { employment within the company or gold panning }\end{array}$ & \\
\hline & $\begin{array}{l}\text { Construction of a } \\
\text { mosque and a church }\end{array}$ & & \\
\hline Religion & & & \\
\hline
\end{tabular}

\subsection{Impact on Plant Species}

Mining activities have created a severe disturbance to the land surface through the destruction of the natural ecosystems such as vegetation which refers to plant species which cover the soil [35]. SMD LGM was covered with various plant species that were victims of human actions as a result of the exploitation. Table 4 shows that 24 plant species belonging to 13 families were identified before the implementation of SMD LGM in the Lèro area and the family with more species is the Caesalpiniaceae with 7 species. During the implementation of the SMD LGM, these species become rare or even disappear in the mining concession and the surrounding village. According to Gutti (2012), deforestation is very dangerous for men, animals, and properties. It decreases soil water $\mathrm{PH}$, some soil macro nutrients [1]. M Kamga (2018) illustrated that vegetation in form of natural forest is usually the first casualty to undergo the impact of mineral exploration and exploitation which can cause the elimination of certain plant species and affect certain animals that feed on such plants. These cause the disturbance of the ecosystem with a possible consequence on the flora and fauna community [36]. 
Table 4. Status of plant species in the SMD Lefa Gold Mine Concession before and during operation, ++: Very species plentiful; +: Abundant species; --: Very threatened; -: Threatened, Source: Service Meteorology of Siguiri (2013).

\begin{tabular}{|c|c|c|c|}
\hline \multirow[t]{2}{*}{ Family } & \multirow[t]{2}{*}{ Scientific names } & \multicolumn{2}{|c|}{ Abundance } \\
\hline & & Before & During \\
\hline \multirow[t]{2}{*}{ Anacardiaceae } & Anacardium occidentale & + & - \\
\hline & Spondias mombin & + & - \\
\hline \multirow[t]{3}{*}{ Bombacaceae } & Adansonia digitata & + & - \\
\hline & Bombax costatum & ++ & + \\
\hline & Ceiba pentandra & ++ & + \\
\hline \multirow[t]{7}{*}{ Cesalpiniaceae } & Afgelia africana & ++ & -- \\
\hline & Detarium guineensis & ++ & + \\
\hline & Cassia siamea & + & - \\
\hline & Isoberina doka & ++ & + \\
\hline & Cassia siberina & & \\
\hline & Danellia oliverii & & \\
\hline & Piliostigma thoningii & + & - \\
\hline Combretaceae & Combertum micranthum & ++ & - \\
\hline \multirow[t]{2}{*}{ Meliaceae } & Kaya senegalensis & ++ & + \\
\hline & Carapa procera & + & - \\
\hline Miosaceae & Parkia biglobosa & ++ & + \\
\hline Moraceae & Ficus capensis & ++ & + \\
\hline Papilionaceae & Pterocarpus erinacens & ++ & + \\
\hline Cornaceae & Lophira laceolata & + & - \\
\hline Rubiaceae & Nauclea latifolia & ++ & + \\
\hline Sapotaceae & Vitellaria paradoxa & ++ & + \\
\hline Sterculiaceae & Cola cordifolia & + & - \\
\hline Verbenaceae & Gmelina arborea & + & + \\
\hline
\end{tabular}

\subsection{Impact on the Fauna}

An ecological investigation was conducted for understanding the fauna of the study area, especially by listing of species and assessing the existing baseline ecological state in the study area [37]. The change created by mining activities to the landscape doesn't allow many animal species to be adapted so that modification reduces their living space. Some impacts are short term and are limited to Mine site but others can have profound repercussion and long-term effects [38]. The mining site of SMD LGM name's Lèro Karta was populated by various animal species that have greatly diminished. The analysis of Table 5 shows that SMD Lefa Gold mine fauna was abundant but is currently threatened by the activities. The most endangered class are mammals including three (3) extinct species in the family Bovidae, two (2) in the family of Felidae and two (2) species in the family of Suidae. This shows that the species in this area tend to disappear gradually if the attenuation and compensation measures are not taken. 
Table 5. Impact on fauna. Legend: ++: very abundant species; +: Abundant species; -: Threatened species; 0: Extinct species; R: Reduced species, Source: Service Meteorology of Siguiri (2013).

\begin{tabular}{|c|c|c|c|c|}
\hline \multirow[t]{2}{*}{ Class } & \multirow[t]{2}{*}{ Family } & \multirow[t]{2}{*}{ Scientific names } & \multicolumn{2}{|c|}{ Abundance } \\
\hline & & & Before & During \\
\hline \multirow{11}{*}{ Mammal } & \multirow{5}{*}{ Bovidae } & Cephalophus rufilatus & + & 0 \\
\hline & & Tragelaphus scriptus & ++ & $\mathrm{R}$ \\
\hline & & Sincerus caffer caffer & + & 0 \\
\hline & & Kobus élipsipryminus & + & 0 \\
\hline & & Erythrocepus patas & ++ & $\mathrm{R}$ \\
\hline & \multirow{2}{*}{ Cercopithelidae } & Cercopithecus aethiopus & + & $\mathrm{R}$ \\
\hline & & Papio cynocphalus & + & 0 \\
\hline & \multirow{2}{*}{ Felidae } & Panthera leo & + & 0 \\
\hline & & Panthera pardus & + & 0 \\
\hline & \multirow[b]{2}{*}{ Suidae } & Phacocerus erytropus & + & 0 \\
\hline & & Potamocerus porcus & + & 0 \\
\hline \multirow{3}{*}{ Reptiles } & Viperniae & Vipera berus & + & $\mathrm{R}$ \\
\hline & Crocodilidae & Crocodylus niloticus & & 0 \\
\hline & Accipitridae & Mycrosirtes monochus & ++ & $\mathrm{R}$ \\
\hline \multirow[t]{2}{*}{ Birds } & Ardeidae & Ardeala ibus & ++ & - \\
\hline & Psitacidae & Poicephalus robusta & ++ & + \\
\hline \multirow{3}{*}{ Amphibians } & Bufonidae & Bufo bulgaris & + & + \\
\hline & Ranidae & Rana esculenta & + & + \\
\hline & & Tilapia niloticus & ++ & $\mathrm{R}$ \\
\hline \multirow[t]{2}{*}{ Fish } & & Clarias dialonensis & + & $\mathrm{R}$ \\
\hline & Cyprinidae & Malterus electricus & + & $\mathrm{R}$ \\
\hline
\end{tabular}

\subsection{Impacts on the Local Population Health}

Mining harms surface and groundwater. Traditional wells recharge from surface water and precipitation, mining by its nature consumes can seriously affect water resources [39] which can be a danger for the surrounding population, which can occur by chemical contamination and pollution, and erosion and sedimentation. Indeed, the diffusion of the contamination in the air, water and towards the biosphere, and the chain may subject people to exposure to metals that may pose a health risk if toxicity thresholds determined by international health surveillance institutions (US EPA, OM) are exceeded [40]. In Table 6 some people suffered from respiratory infection (9.28\%) in January and (4.88\%) in February as well as other diseases (2.36\%).

Those related to mine such as malaria (41.51\%) from January to February was the most common disease of the population, dermatoses (5.86\%), Typhoid Fever (6.72\%), gastritis (1\%). 
Table 6. The main diseases identified in the locality and their probable causes during the months of January and February 2011, source: Lèro Karta Health community service (2011).

\begin{tabular}{|c|c|c|c|c|c|c|c|}
\hline \multirow[t]{2}{*}{ Pathology } & \multirow[t]{2}{*}{ The probable source of diseases } & \multicolumn{6}{|c|}{ Numbers of patients } \\
\hline & & January & Percentage $(\%)$ & February & Percentage (\%) & Total & Percentage (\%) \\
\hline Malaria & Mosquito bites & 468 & 22.61 & 390 & 18.9 & 858 & 41.51 \\
\hline Intestinal parasites & Lack of hygiene & 170 & 8.21 & 92 & 4.44 & 262 & 12.65 \\
\hline Dermatoses & Lack of hygiene, drug, chemical & 43 & 2.1 & 78 & 3.76 & 121 & 5.86 \\
\hline $\begin{array}{l}\text { Acute respiratory } \\
\text { infections }\end{array}$ & Excessive dust, drug, chemical & 192 & 9.28 & 101 & 4.88 & 293 & 14.16 \\
\hline Typhoid Fever & Lack of hygiene, chemical & 62 & 3 & 77 & 3.72 & 139 & 6.72 \\
\hline Anemia & Lack of hygiene, chemical & 7 & 0.33 & 25 & 1.2 & 32 & 1.53 \\
\hline Acute gastronomy & Excessive dust, drug, chemical & 52 & 2.51 & 28 & 1.35 & 80 & 3.86 \\
\hline $\begin{array}{l}\text { Urogenital } \\
\text { infections }\end{array}$ & Lack of hygiene, chemical, other & 128 & 6.2 & 86 & 4.15 & 214 & 10.35 \\
\hline Gastritis & Excessive dust, drug, chemical & 7 & 0.33 & 14 & 0.67 & 21 & 1 \\
\hline Others & Others & 40 & 1.93 & 9 & 0.43 & 49 & 2.36 \\
\hline Total & & 1169 & $56.50 \%$ & 900 & $43.50 \%$ & 2069 & $100 \%$ \\
\hline
\end{tabular}

The result of the extraction of the ore and the process used to get the gold from its ore make LGM activities the main cause of environmental pollution and the socioeconomic impact of the study area. The activities affect negatively the environment by polluting the surrounding rivers, air, farmland, landscape degradation but it's also established that the physical health of people living around the area was impacted [2]. K. Joseph (2018) illustrated that the use of a toxic substance such as cyanide can affect the close water bodies which are not good for domestic purposes [41].

\section{Mitigation Measures}

Make a social impact assessment (SIA) prior to mining and to assure any major risks identified are appropriately mitigated [42]; according to the research found above, a serial of measures is provided for good management and accountability following the implementation of the national strategy for biodiversity conservation and sustainable resource use in two levels of intervention: First, the conservation of environmental resources in its diversity; second, the sustainable use of environmental resources and international cooperation; The first intervention is to safeguard biological, physical and human environments by protecting species, habitats, ecosystems and the atmosphere. The company has to validate renewable and non-renewable resources sustainable, to pick up, place and properly dispose of all waste products that may cause damage to the environment or to health which can help to reduce the risk of contamination; backfill if possible the mining wells or reforest fast-growing species on the waste rock or in the offsets. LGM has to cooperate to understand the social, cultural and environmental value of wa- 
ter in mine catchment. In the second intervention, LGM for the development of the population and locality have to invest in the search and education by communicating with them to let them know the mining development project for the locality and consider the need of the local population for the socioeconomic development.

\section{Conclusions and Recommendations}

Over multiple scales, the relationships between mining and stakeholder's environment are complex and interactive. The SMD Lefa gold mine is for Guinea and the local population a source of income, which is explained by job creation, the increase in the gross domestic product (GDP) and, the raising of the standard of living of the population. However, this activity dangerously affects the ecological balance in all its components. This is not because mitigation measures are not taken by the company, but their applications remain insufficient, especially at the rehabilitation and restoration area. The assessment of the impacts of SMD LGM activities on the natural resources of the study area has shown that mineral extraction has a greater impact on natural resources and the maintenance works have little impact. This has led to serious ecological disturbances and profound changes characterized by the scarcity of certain animal and plant species, the modification or deformation of the relief; the pollution of the atmosphere by smoke, gases and dust and the surface water and groundwater pollution by chemicals organic such as cyanide, caustic, soda and hydrochloric acid. Karta stream is one of the streams used by the surrounding population so the deviation for mining purpose can increase the frequency of diseases because of contamination. In the light of the above we recommend to SMD LGM to reforest all the perimeters of the mining concession that does not contain the ores requested by the company, or find compensation lands; make a hedge along the lagoon to prevent animal straying into the area; have a progressive rehabilitation plan, integrated with mining operations, which includes completion criteria; close abandoned mines or turn them into fishponds after exploitation; make dynamic the environmental service within to undertake good conservation of stripped land for future re-use; reforest slag heaps to prevent erosion to prevent sedimentation at the field level; prevent stray animals to sites on farms; introduce local species to attract wildlife; install dust extraction machines near crushers and wherever dust is raised; water abundantly, and at all times, already open tracks and mine ramps; muffling machine to reduce noise; keeping the surrounding population at a safe distance from mines; require mine workers to use safety equipment; reduce the number of holes that explode at the same time; detoxify waste at the residue level and provide enough umbrellas for mine workers because of the sun; consider the requirement for economic mitigating measures or restitution for loss of land use and its other community values; have a closing plan, developed with local stakeholders and agreed with regulators; understand the health needs of the local population and how these relate to the needs of mine operation; understand and project to preserve cultural heritage pertinent to the mining area and use a risk-based 
approach to include and manage potential impacts from the mine. Fundamentally, the company assures the good physical safety of the residue lake, which should be regularly monitored and maintained, to avoid any animal or anyone close to the Lake to access it.

\section{Acknowledgements}

This work is supported in part by grants from the National Science Foundation of China $(41430106,41720104007,41573080,41711530030,41711530150)$ and project of the Ministry of Science and Technology of China (S2016G2135).

\section{Conflicts of Interest}

The authors declare no conflicts of interest regarding the publication of this paper.

\section{References}

[1] Gutti, M., Aji, M. and Magaji, G. (2012) Environmental Impact of Natural Resources Exploitation in Nigeria and the Way Forward. Journal of Applied Technology in Environmental Sanitation, 2, 95-102.

[2] Mathe, M. and Phiri, A. (2016) The Impact of Mining on the Environment in Gwanda District Zimbabwe: A Case Study of Blanket Mine. Imperial Journal of Interdisciplinary Research, 2, 503-512.

[3] Rowley, J., Souza, K.D. and Armstrong, W. (2007) Synergy_2007_CDF_Mining_Guinea. http://www.synergy-global.net

[4] Lefa Gold Mine (2009) Disclosure of Mineral Resources and Reserves, Lefa Gold Mine, Northeast Guinea Technical Report Update.

https://www.google.com/url?sa=t\&rct=j\&q=\&esrc=s\&source=web\&cd=1\&cad=rja\& uact=8\&ved=2ahUKEwiQjfGe0I7kAhWWFYgKHXrACeAQFjAAegQIAhAC\&url= http\%3A\%2F\%2Fwww.miningdataonline.com\%2Freports\%2FLefa_2009_TR.pdf\&u sg=AOvVaw2eHoztOIAcKJ_218uV_SM

[5] Cooke, J.A. and Johnson, M.S. (2002) Ecological Restoration of Land with Particular Reference to the Mining of Metals and Industrial Minerals: A Review of Theory and Practice. Environmental Reviews, 10, 41-71. https://doi.org/10.1139/a01-014

[6] Melodi, M.M. (2017) Assessment of Environmental Impacts of Quarry Operation in Ogun State, Nigeria. FUOYE Journal of Engineering and Technology, 2, 100-103.

[7] Remoundou, K. and Koundouri, P. (2009) Environmental Effects on Public Health: An Economic Perspective. International Journal of Environmental Research and Public Health, 6, 2160-2178. https://doi.org/10.3390/ijerph6082160

[8] Getaneh, W. and Alemayehu, T. (2006) Metal Contamination of the Environment by Placer and Primary Gold Mining in the Adola Region of Southern Ethiopia. Environmental Geology, 50, 339-352. https://doi.org/10.1007/s00254-006-0213-5

[9] Luque-Almagro, V.M., Moreno-Vivián, C. and Roldán, M.D. (2016) Biodegradation of Cyanide Wastes from Mining and Jewellery Industries. Current Opinion in Biotechnology, 38, 9-13. https://doi.org/10.1016/j.copbio.2015.12.004

[10] Christine, L., Anderson, H. and Karoui, H. (2017) Prediction Model for Cyanide Soil Pollution in Artisanal Gold Mining Area by Using Logistic Regression. Catena, 162, 40-50. https://doi.org/10.1016/j.catena.2017.11.018

[11] Christine, L., Anderson, H., Karoui, H., Podgorski, J. and Yacouba, H. (2018) Cate- 
na Prediction Model for Cyanide Soil Pollution in Artisanal Gold Mining Area by Using Logistic Regression. Catena, 162, 40-50. https://doi.org/10.1016/j.catena.2017.11.018

[12] Porgo, M. and Gokyay, O. (2016) Environmental Impacts of Gold Mining in Essakane Site of Burkina Faso. Human and Ecological Risk Assessment: An International Journal, 23, 641-654. https://doi.org/10.1080/10807039.2016.1263930

[13] Kamga, M.A., et al. (2018) Sustainable Development and Environmental Challenges in Cameroon's Mining Sector: A Review. Journal of Mining \& Environment, 9, 293-309. https://doi.org/10.20897/ejosdr/85117

[14] Akpalu, W. and Normanyo, A.K. (2016) Gold Mining Pollution and the Cost of Private Healthcare: The Case of Ghana. WIDER Working Paper Series 121, World Institute for Development Economic Research, Helsinki.

[15] Wegenast, T., Strüver, G., Giesen, J. and Krauser, M. (2018) At Africa's Expense? Disaggregating the Social Impact of Chinese Mining Operations.

https://doi.org/10.2139/ssrn.3128793

[16] Mudder, T.I. and Botz, M.M. (2004) Cyanide and Society: A Critical Review. European Journal of Mineral Processing and Environmental Protection, 4, 62-74.

[17] Kaye, J.L. (2018) Republic of Guinea 2009-17.

[18] Bakirdjian, M., Bulakali, A. and Pays, D. (2016) Analyse des conflits miniers en Haute Guinée. http://www.sfcg.org

[19] Ida, F. (2018) Ministere de L'agriculture projet de développement Agricole Intégré de la Guinée (PDAIG).

https://waappguinee.org/wp-content/uploads/2018/04/CGES-PDAIG-_revue-vf.pdf

[20] Unies, N. and Document, G. (2010) Programme des Nations Unies pour le développement Pays: GUINEE Document de projet. Croissance et la promotion d opportunités d e mplois et de revenus pour tous c Réduction de la vulnérabilité et 1 amélioration des conditions de vie Résultat(s).

https://www.google.com/url?sa=t\&rct=j\&q=\&esrc=s\&source=web\&cd=1\&cad=rja\& uact=8\&ved=2ahUKEwjx3MKM_obkAhVWx4sBHc1BBcsQFjAAegQIABAC\&url= https\%3A\%2F\%2Finfo.undp.org\%2Fdocs\%2Fpdc\%2FDocuments\%2FGIN\%2FMini ng\%2520and\%2520SHD_Guinea\%2520prodoc\%2520BPAC\%2520(4).pdf\&usg=AO vVaw2DqMTiBVxEHqffqDwtOCtM

[21] Emmanuel, A.Y., Jerry, C.S. and Dzigbodi, D.A. (2018) Review of Environmental and Health Impacts of Mining in Ghana. Journal of Health and Pollution, 8, 43-52. https://doi.org/10.5696/2156-9614-8.17.43

[22] Sturman, K., Rogers, P., Imbrogiano, J., Mori Junior, R. and Ezeigbo, C. (2018) Monitoring Impact of Mineral Sustainability Standards to Align with the Sustainable Development Goals. Centre for Social Responsibility in Mining (CSRM), The University of Queensland, Brisbane. http://www.csrm.uq.edu.au

[23] Neris, J.B., Olivares, D.M.M., Velasco, F.G., Luzardo, F.H.M., Correia, L.O. and González, L.N. (2019) HHRISK: A Code for Assessment of Human Health Risk Due to Environmental Chemical Pollution. Ecotoxicology and Environmental Safety, 170, 538-547. https://doi.org/10.1016/j.ecoenv.2018.12.017

[24] Hamann, R. (2003) Mining Companies' Role in Sustainable Development: The "Why" and "How" of Corporate Social Responsibility from a Business Perspective. Development Southern Africa, 20, 237-254. https://doi.org/10.1080/03768350302957

[25] 2011 CPR Access Report on the Assets of Nord Gold for Guinea Section (2011) Location, Access and Infrastructure. 145-285. 
https://www.rns-pdf.londonstockexchange.com/rns/2287a_2-2011-1-27.pdf

[26] NORD GOLD (2011) CPR Report on the Assets of Nord Gold for Burkina Faso, Guinea, Kazakhstan and the Russian Federation.

https://www.google.com/url?sa=t\&rct=j\&q=\&esrc=s\&source=web\&cd=9\&cad=rja\& uact=8\&ved=2ahUKEwiQjfGe0I7kAhWWFYgKHXrACeAQFjAIegQIBxAC\&url=h ttp\%3A\%2F\%2Fwww.rns-pdf.londonstockexchange.com\%2Frns\%2F2287a_3-20111-27.pdf\&usg=AOvVaw3tYiud7fa4JiO-433-aQUG

[27] Ralph, O., Gilles, N., Fon, N., Luma, H. and Greg, N. (2018) Impact of Artisanal Gold Mining on Human Health and the Environment in the Batouri Gold District, East Cameroon. Academic Journal of Interdisciplinary Studies, 7, 25-44. https://doi.org/10.2478/ajis-2018-0003

[28] Beth, A.A. (2018) Assessment of Occupational Safety Compliance in Small-Scale Gold Mines in Siaya County, Kenya. https://scholar.google.com/scholar

[29] Newmont, O.F., et al. (2010) The Social and Environmental Impacts of Mining Activities on Indigenious Communities.

https://www.google.com/url?sa=t\&rct=j\&q=\&esrc=s\&source=web\&cd=1\&ved=2ahUK Ewiw7KP4jofkAhWCKqYKHRpUDoIQFjAAegQIAhAC\&url=https\%3A\%2F\%2Fuia.b rage.unit.no\%2Fuia-xmlui\%2Fbitstream\%2Fhandle\%2F11250\%2F135149\%2FJones \%2520Opoku-Ware.pdf\%3Fsequence\%3D1\&usg=AOvVaw0VopjuoNIZ6tvczDOL D3Ie

[30] Di Noi, C., Ciroth, A., Karakaya, E. and Nuur, C. (2018) Social Sciences and the Mining Sector: Some Insights into Recent Research Trends. Resources Policy, 58, 257-267. https://doi.org/10.1016/j.resourpol.2018.05.014

[31] Mancini, L. and Sala, S. (2018) Social Impact Assessment in the Mining Sector: Review and Comparison of Indicators Frameworks. Resources Policy, 57, 98-111. https://doi.org/10.1016/j.resourpol.2018.02.002

[32] Amponsah-Tawiah, K. and Dartey-Baah, K. (2011) Corporate Social Responsibility in Ghana. International Journal of Business and Social Science, 2, 107-111.

[33] Kamga, M.A., et al. (2018) Review of Environmental and Health Impacts of Mining in Ghana. Journal of Mining \& Environment, 9, 293-309.

[34] Sonter, L.J., Ali, S.H. and Watson, J.E.M. (2020) Mining and Biodiversity Key Issues and Research Needs in Conservation. Proceedings of the Royal Society of London. Biological Sciences, 285, pii: 20181926.

[35] Unanaonwi, O.E. and Amonum, J.I. (2017) Effect of Mining Activities on Vegetation Composition and Nutrient Status of Forest Soil in Benue Cement Company, Benue State, Nigeria. International Journal of Environment, Agriculture and Biotechnology, 2, 297-305. https://doi.org/10.22161/ijeab/2.1.39

[36] Kamga, M.A., et al. (2018) Perception of the Environmental Degradation of Gold Mining on Socio-Economic Variables in Eastern Cameroon, Cameroon. European Journal of Sustainable Development Research, 2, 23. https://doi.org/10.20897/ejosdr/85117

[37] Biswas, S. and Biswas, A. (2018) Impact of Mining on Forests and Its Biological Diversity at Kirandul Iron Ore Mines, Dantewada, South Bastar, Chhattisgarh: A Case Study. Journal of Environmental Science Studies, 1, 16. https://doi.org/10.20849/jess.v1i1.420

[38] Pour, M., Tion, O., Master, D.U., Sciences, E.N., De, I. and Aicha, B. (2016) Proposition d'un plan de rehabilitation de la mine a systeme de heap leaching du projet bouly.

$\underline{\text { https://www.google.com/url?sa=t\&rct=j\&q=\&esrc=s\&source=web\&cd=1\&cad=rja\& }}$ 
uact=8\&ved=2ahUKEwjQn4-gkYfkAhV7wosBHfCMDpYQFjAAegQIABAC\&url= http\%3A\%2F\%2Fdocumentation.2ie-edu.org\%2Fcdi2ie\%2Fopac_css\%2Fdoc_num. php\%3Fexplnum_id\%3D2448\&usg=AOvVaw0626n1NCFn918ZUNU6WqLx

[39] De Janeiro, R. and Lamego, F. (2008) Associação Brasileira De Energia Nuclear. 2009 International Nuclear Atlantic Conference (INAC 2009) Rio de Janeiro, RJ, 27 September-2 October 2009.

[40] Wu, J., et al. (2018) Risk Assessment and Source Identification of Toxic Metals in the Agricultural Soil around a $\mathrm{Pb} / \mathrm{Zn}$ Mining and Smelting Area in Southwest China. International Journal of Environmental Research and Public Health, 15, 1838.

[41] Joseph, K., Junior, K. and Matsui, K. (2018) The Impact of Environmental Degradation by Surface Mining on Sustainable Agriculture in Ghana. International Journal of Food and Nutrition Research, 2018, 1-5.

[42] Edition, F. (2018) Sustainable Bauxite Mining Guidelines. World Alum. http://www.world-aluminium.org 